\title{
World Environment Day: Guest Comment
}

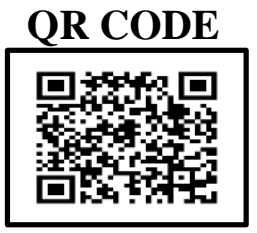

The word environment has been derived from the French word "Environ" meaning as "surroundings".

Environment consists of many variables including air, water, land and all inter relationships which exist between them. Components of environmental elements includes physical, chemical, biological, social and cultural.

Natural environment consists of many interlinkages system-the atmosphere, the hydrosphere, the lithosphere and the biosphere. According to International Epidemiological Association, environment is defined as "All that is external to the human host". All the living organisms such as plants, animals, microorganisms and human beings as well as the physical surroundings interact with each other and maintain a harmonious balance in nature.

Thus all the interacting organisms together with the non-living constituents of the environment form an ecosystem. It is our responsibility as a health care professionals and responsible citizens to maintain the equilibrium and balance between all variables of environment

\section{Raising the Awareness}

From the last several decades, several environmental problems such as pollution both air-water, ozone layer depletion, acid rain, deforestation have remained major thrust areas for various policy makes globally. Environmental protection is a practice of protecting the natural environment on individual, organizational or governmental levels, for the benefit of both the environment and humans. Environment destruction caused by humans is a global worldwide problem which is ongoing every day. By year 2050, the global human population is expected to grow by 2 billion people. The effects of human on Earth can be seen in many ways. The first one is the temperature 1. rise "the global warming" that has been going on for the past 50 years is primarily due to human activities.

In order to raise \& address environmental issues at a regional, national or international level by government organizations. The largest international agency, was set up in 1972, the United Nations Environment Programme. The International Union for Conservation of Nature brings together 83 states, 108 government agencies, 766 Non-governmental organizations and 81 international organizations and about 10,00o experts and scientists from countries around the world.

Environment provides us both renewable and nonrenewable resources. Over usage of renewable resources results in depletion of non-renewable resources. Environmental awareness serves as a very important tool as it develops a sense of connection to the natural world, promotes sustainable development and encourages conservation of irreplaceable natural resources and vulnerable plant and animal species. In order to enhance the awareness worldwide regarding global threat to environment, United Nations marks the environment day every year on 5 th June. It has started in 1974 and since then the event has become a global platform which is celebrated in more than 100 countries. The Government of India should also takes the initiative to conduct an awareness program on the occasion of World Environment Day by highlighting it as "Green week".

Initiatives are also encouraged for conducting "EcoInnovation" and awards are being provided for the same as motivational tool.

The theme of World Environment day 2019 was "Air pollution" and the host country was China. Approximately worldwide 7 million people die prematurely each year with around 4 million deaths occurring in Asia Pacific due to Air-pollution.

There are five main sources of Air-Pollution: -

1. Household: The main source of household air pollution is the indoor burning of wood, fossil fuels and other biomass-based fuels to cook, heat and light homes. Around 3.8 million premature deaths are caused by indoor air pollution each year, majority of 
them in the developing world. Out of 193 countries, 97 countries have increased the percentage of households that have access to cleaner burning fuels to over 85 percent. However, 3 billion people continue to use solid fuels and open fires for cooking, heating, and lighting. The adoption of cleaner, more modern stoves and fuels can reduce the risks of illness due to air-pollution and save lives.

2. Industry: In many countries, power generation is a leading source of air pollution. Coal-burning power plants are a major contributor, while diesel generators are a growing concern in off-grid areas. Industrial processes and solvent use, in the chemical and mining industries, also pollute the air.

Nationwide policies and programmes aimed at increasing energy efficiency and production from renewable sources have a direct impact on a country's air quality. At the moment, 82 countries out of 193 have incentives that promote investment in renewable energy production, cleaner production, energy efficiency and pollution control.

3. Transport: The global transport sector accounts for almost one-quarter of energy-related carbon dioxide emissions and this proportion is rising. Air pollution emissions from transport have been linked to nearly 400,00o premature deaths. Almost half of all deaths by air pollution from transport are caused by diesel emissions, while those living closest to major traffic arteries are up to 12 percent. Reducing vehicle emissions is an important intervention to improve air quality, especially in urban areas. Policies and standards that require the use of cleaner fuels and advanced vehicle emissions standards can reduce vehicle emissions by 90 percent or more.

4. Agriculture: The major sources of air pollution from agriculture include livestock, rice paddies which produces methane and ammonia and the burning of agricultural waste. Methane emissions contribute to the formation of ground-level ozone, which causes asthma and other respiratory illnesses. Methane is also a more potent global warming gas than carbon dioxide.

There are many ways to reduce air pollution from agriculture. People can move to a plant-based diet and/or reduce food waste, while farmers can reduce methane from livestock by optimizing feed digestibility and improving grazing and grassland management.
5. Waste: Open waste burning and organic waste in landfills release harmful dioxins, furans, methane, and fine particulate matter like black carbon into the atmosphere. Globally, an estimated 40 percent of waste is openly burned. The problem is most severe in urbanizing regions and developing countries. Open burning of agricultural and municipal waste is practiced in 166 out of 193 countries.

Improving the collection, separation, and disposal of solid waste reduces the amount of waste that is burned or land filled. Separating organic waste and turning it into compost or bioenergy improves soil fertility and provides an alternative energy source. Reducing the estimated one-third of all food that is lost or wasted can also improve air quality.

\section{Other sources of Air Pollution}

Air pollution does not develop entirely from human activity. Volcanic eruptions, dust storms and other natural processes also causes air pollution. Sand and dust storms are particularly dangerous. Fine particles of dust can travel thousands of miles on the back of these storms, carrying pathogens and harmful substances, leading to acute and chronic respiratory problems.

World environment day acts as a benchmark in motivating governments, industries, communities and individuals to jointly explore renewable energy, green technology innovation and improve air quality in cities and region across the world. World environment day is a United national environment led global event which is celebrated every year on $5^{\text {th }}$ June. It provides encouragement in caring for the environment by improving, informing and enabling nations to improve their quality of life without compromising that of future.

With the same mission of environmental protection, the Government of India under Ministry of Environment Forest and Climate Change has enacted "The Environment Protection act" with the main objective for the protection and improvement of the environment. It empowers the central Government to establish authorities [under section 3] charged with the mandate of preventing environmental pollution in all its forms and to tackle specific environmental problems that one peculiar to different parts of the country.

Thus, we all should join hands together in saving our planet earth by conserving natural resources and 
existing natural environment with same mission of environmental protection.

Cite this article as:

Sharma S. World Environment Day: Guest Comment. Int Healthc Res J. 2019;3(3):93-95. https://doi.org/10.26440/IHRJ/0303.06251

Author Details \& Corresponding Address:

Dr. Swati Sharma

Reader and Staff Incharge

Department of Public Health Dentistry

School of Dental Sciences

Sharda University, Greater Noida

Swati.sharma@sharda.ac.in 